\title{
Brief Biography of Hugh MacDiarmid
}

'Hugh MacDiarmid' was born Christopher Murray Grieve on 11 August 1892 in Langholm in the Scottish Borders. His father James was a postman, his mother Elizabeth caretaker of the local library. Grieve was taught by the composer Francis George Scott at Langholm Academy and in 1908 himself embarked on teacher training in Edinburgh, but left without taking a qualification. Having entered journalism, he worked for a series of local newspapers in Scotland and Wales before World War One. During the war Grieve served as a non-combatant with the Royal Army Medical Corps in Salonika and France. When he was demobilised, he returned to Scotland and married Margaret Skinner. The couple settled in Montrose where Grieve worked for the Montrose Review, becoming also a town councillor and Justice of the Peace. It was in Montrose in 1922 that Grieve created MacDiarmid, the most famous of his many pseudonyms, and it was from the Angus town that he launched the movement popularly known as the 'Scottish Renaissance'. As editor and publisher he produced the anthology Northern Numbers (1920-2), and the magazines Scottish Chapbook (1922-3), Scottish Nation (1923) and Northern Review (1924). His first published work as author, Annals of the Five Senses, a collection of avant-garde short stories and poetry, appeared under his family name of Grieve in 1923. However he found his true voice as the poet Hugh MacDiarmid when, influenced by Jamieson's Etymological Dictionary of the Scottish Language, he began to write experimental lyrics in Scots. Sangschaw (1925) and Penny Wheep (1926) brilliantly exemplified his 'Synthetic Scots' style, while the 2,685 lines of A Drunk Man Looks at the Thistle (1926), also in Scots and often regarded as MacDiarmid's greatest poetic achievement, combined the form and influences of international modernism with philosophical searching and reflections on the state of modern Scottish culture. Contemporary Scottish Studies (1926), essays first appearing in The Scottish Educational Journal, and Albyn; or Scotland and the Future (1927), illustrated his ambitious cultural and political aims for Scotland. Grieve became a member of the newly-formed National Party of Scotland in 1928, but left Scotland for London the following year to work 
for Compton Mackenzie's radio-magazine Vox. Neither the magazine nor his move to England was a success, and the venture ended in his unemployment and in the breakdown of his marriage. His personal difficulties during this period - he was hospitalised in 1935 after suffering a nervous breakdown are reflected in To Circumjack Cencrastus (1930) and in 'Ode to All Rebels' (deleted from the first edition of Stony Limits in 1934).

In 1933 Grieve moved to the Shetland island of Whalsay with his second wife Valda Trevlyn. His First Hymn to Lenin (1931) had demonstrated a deepening radicalism that saw him expelled from the National Party of Scotland in 1933, and he joined the Communist Party of Great Britain in 1934. Second Hymn to Lenin was published in 1935, but this was followed by his expulsion from the Communist Party in Scotland for nationalist deviation in 1938. Scots Unbound (1932) was his last sustained use of the Scots language in his poetry; with Stony Limits (1934) he moved to scientific terminology and erudite dictionary English, most effectively in 'On a Raised Beach', which also reflected the geological sparseness of his new island environment. From Shetland he published the prose works Scottish Scene (1934), co-authored with Lewis Grassic Gibbon, Scottish Eccentrics (1936) and The Islands of Scotland (1939). Lucky Poet, his fiery autobiography, appeared in 1943; a second volume of personal recollection, The Company I've Kept, in 1966. Much of his later poetry, notable amongst which is In Memoriam James Joyce (1955), had been written by the time he left Shetland in 1942 to work in munitions in Glasgow. A Kist of Whistles (1947), Three Hymns to Lenin (1957), The Battle Continues (1957) and The Kind of Poetry I Want (1961) preceded his first Collected Poems, published in 1962. Continuing to 'aye be whaur / Extremes meet' Grieve rejoined the Communist Party in 1957 and listed his hobby in Who's Who as Anglophobia. He died on 9 September 1978, the year his Complete Poems was issued. Some formerly undiscovered poems were published amidst controversy in 2003 as The Revolutionary Art of the Future. 